\title{
Home ownership and asset-based welfare
}

\author{
John Doling • Richard Ronald
}

Received: 8 December 2009/ Accepted: 8 December 2009/Published online: 10 January 2010

(C) The Author(s) 2010. This article is published with open access at Springerlink.com

\section{Introduction}

In recent decades, the notion of an 'asset-based' or 'property-based' welfare system has become increasingly central to debates on the restructuring of western welfare states (Groves et al. 2007; Regan and Paxton 2001; Sherraden 2003; Watson 2009). The principle underlying an asset-based approach to welfare is that, rather than relying on state-managed social transfers to counter the risks of poverty, individuals accept greater responsibility for their own welfare needs by investing in financial products and property assets which augment in value over time. These can, at least in theory, later be tapped to supplement consumption and welfare needs when income is reduced, for example, in retirement, or used to acquire other forms of investment such as educational qualifications.

Several socioeconomic developments have helped to advance the cause of asset-based welfare. On one side has been a combination of pressures brought on by the ageing of national populations and their expected impact on pensions and public welfare resources, along with government retrenchment of public welfare provision associated with neoliberalisation. On the other has been, until very recently at least, expanding home ownership rates and increases in housing property values across most economically advanced economies. Essentially, the potential wealth tied up in owner-occupied housing has been considered, more or less explicitly, to be a solution to the fiscal difficulties involved in the maintenance of welfare commitments, and through that, the asset in asset-based welfare has frequently become property or housing asset (Doling and Ford 2007).

J. Doling

College of Social Sciences, University of Birmingham, Birmingham, UK

R. Ronald $(\square)$

OTB Research Institute, Delft University of Technology, Delft, The Netherlands

e-mail: r.ronald@tudelft.nl

R. Ronald

Urban Studies, Department of Geography, Planning and International Development Studies, University of Amsterdam, Amsterdam, The Netherlands 
This themed edition considers both the potential and the limitations of home ownership as a means of offsetting welfare and pension needs in the context of socioeconomic and demographic transformations. The objective is neither to condone nor condemn assetbased welfare-irrespective of whether the assets are property - but rather to examine how it has already been developed and tested in a number of countries and to explore its viability in the context of changes evidently underway in many advanced societies. The objective is also not to suggest that asset-based welfare is the policy destiny of advanced societies, but rather that home ownership has taken on a new and more global salience in welfare policy and politics, and, because of that, requires attention. To these ends, both individual societies and groups of countries that represent asset-based welfare and housing systems at different stages and in different conditions have been selected for analysis. All, however, provide lessons on, and insights into, the potential and limitations of housing as a pillar of welfare.

Before considering the papers set out in this edition it is useful first to establish further the features and dimensions of housing, welfare and household assets.

\section{Housing and welfare}

Historically, housing was viewed as one of the major determinants of the standard of living achieved by households, it having a direct bearing, literally, on how well households lived. Decent housing, in the sense of an adequate physical shelter, was the solution to one of Beveridge's five giants: squalor. Consequently, when Torgersen coined his now famous phrase "the wobbly pillar under the welfare state" (Torgersen 1987) he was referring to housing as 'shelter' and the limited scope of housing services provided by the state, normally taken to mean non-profit rental housing. However, this always underrepresented the full significance of housing. In practice, social security systems complement and integrate with other related measures. It has thus been argued that by addressing the housing system more as a whole, to include the private market, housing can be considered central to household welfare conditions (Groves et al. 2007). Housing is a complex welfare good that supplements and mediates the flow of other welfare goods and services at the household level, making individuals more or less dependent on the state, market and family for the satisfaction of other needs. But increasingly, as levels of individual housing property consumption and, subsequently, housing wealth expand, the capacity for households to tap into this wealth for the purchase of welfare goods or to offset retirement needs also increases. The position of housing in national welfare systems, then, is much more complex than its role simply as providing physical shelter.

One aspect of this complexity, the significance of home ownership and family welfare exchanges, has been reasonably well documented in Southern European states (Castles and Ferrera 1996; Allen et al. 2004). There, it has been considered to reflect cultural values, family practices and the underdevelopment of the welfare state. However, the geographically wider perspective established through the work of Kemeny (1981) and Castles (1998) points to a possible trade-off between the extent of home ownership and the generosity of pensions in old age. By the time of retirement, older un-mortgaged homeowners generally enjoy the net benefit equivalent to the rent they would otherwise have to pay on the property minus outgoings for maintenance and property taxes. In other words, 'when individuals own homes they can get by on smaller pensions' (Castles 1998, 13). At the same time, the resources required for paying for a home act as a strong deterrent to welfare and social security funded by increases in taxation. Kemeny (1981) provided 
evidence for these effects by comparing aggregate measures of welfare with levels of home ownership, while Castles (1998) conducted more rigorous cross-country testing, finding significant, inverse statistical relationships between home ownership and welfare rates, which, he argued, was indicative of different models of providing welfare.

Such relationships have come under increasing scrutiny in recent years, one result being the recognition that the connections between housing and welfare systems vary considerably from country to country. Ritakallio's (2003) comparison of Australia and Finland found that the inclusion of housing costs in the calculation of disposable income reduced the differences in poverty and equality levels that appeared 'before housing costs', but to an extent that varied by country. Conley and Gifford (2003) also identify a number of countries where home ownership is an important policy mechanism in ameliorating the detrimental social effects of market forces in the absence of redistributive programmes. Nonetheless, evidence that home ownership constitutes a functional alternative to public welfare spending or can be structured in such a way as to reduce social inequality rather than enhancing it is limited (Fahey et al. 2004). More recently, Dewilde and Raeymaeckers (2008) provide evidence to suggest that while high home ownership rates appear to have poverty-reducing potential for pensioners, contexts are complicated by the specific interplay of social transfer and housing policies in each society. Specifically, they found a double disadvantage experienced by those who do not or cannot buy their own homes in countries with high home ownership rates. They also established that low rents in the social housing sector in some countries may also offset low incomes among the elderly.

\section{Assets and policies}

In recent years, concerns about the future of national welfare systems have led to many governments pursuing policy programmes promoting the uptake of individual asset building. There have been a number of initiatives. In the USA, Individual Development Accounts have since 1997 encouraged lower-income groups to save by matching contributions with public funds. The total amount of money saved can typically be used for funding house purchase, education, setting up a small business, or a pension annuity (McKay 2002). In the UK, the Savings Gateway also matches savings for those with lower incomes, while the Child Trust Fund provides all new-born children with a lump sum payment from the taxpayer into a personal account, accessible when they reach 18 . Underlying these schemes is the assumption that future needs could and should be selffunded and, furthermore, that policy should play a part in encouraging such behaviour.

Housing markets have been at the core of these policies, as home purchase is normally considered the most appropriate investment vehicle for government supported saving. Malpass (2008, p. 2) suggests that the more dominant the private housing market has become the more it has been perceived as a potential cornerstone of the new welfare state. Movement in housing markets has provided ostensible opportunities for individuals to build their wealth through progress up a housing ladder, through the trade in homes and even investment in properties to rent out. This has helped transform housing policies with social rental housing residualisation and the transfer of subsidies to support intermediate and owner-occupied housing.

Along with government reorientation around savings and assets, housing has also become increasingly significant as a market commodity. It has been argued that owneroccupied housing has thus become central under the ethos of asset-based welfare to an intensification of exchange relations and the financialization of everyday life (Langley 
2008; Ronald 2008). Policies and discourse have associated future aspirations and selfprovisioning with the pricing dynamics of asset markets. Governments too have become involved in promoting financial literacy among the population, while the notion of the saver-investor has become a central economic identity and normalised feature of contemporary existence. 'The calculations of everyday life thus come to mimic those of professional investors: how to treat life itself as a series of investment decisions; how to position the household's assets on the right side of pricing trends; and how to plan for the long term by being able to continually trade up the value of assets' (Watson 2009, p. 45).

But, as attractive as asset-based welfare might appear to governments, a number of obstacles have stood in the way of its development. Firstly, while governments appear to have assumed that individuals are rational economic agents that would choose to save in the face of expectations of future welfare shortfalls, evidence of this is equivocal. Rowlingson (2002), for example, argues that people face constraints in thinking and planning ahead and saving for the future. These may lie in difficulties or unwillingness to think long term into the future or to imagine one's place in it. Furthermore, for some, conceptions of the lifecycle lead them to consider particular types of planning at particular ages, while for others the ability to plan ahead is affected by the amount and security of resources that they command.

Secondly, in regard to whether or not households accumulate housing wealth as part of a long-term strategy, as house prices have increased, the regular savings and costs associated with purchase have moved well beyond the capacity of many households, especially ones with a low income or only one earner. In the UK, the rate of net income required to serve mortgage repayments increased from 25 to $42 \%$ between 2003 and 2007. Meanwhile, the equivalent proportion required to cover the up-front costs of home purchase increased from around 20 to 100\% between 1997 and 2004 (RICS 2007). Home purchase has thus become increasingly delayed requiring long-term strategies and savings plans. And, most of all, large sections of the populations in all countries are financially excluded from acquiring housing assets at all so that a property-based system of welfare will not be fully inclusive of national populations.

Thirdly, while many have been able to acquire housing investments which have in the long term increased in value, it has proved difficult to either transform such fixed assets into liquid resources for welfare consumption or get people to accept that housing wealth should be consumed, especially on welfare services. While the income in-kind enjoyed by non-mortgaged homeowners supplements lower incomes, it is more difficult to extract asset value from a home. Traditional mechanisms require trading down or moving into rented accommodation, undermining the advantages of owner-occupation. Haffner (2008) found that Dutch homeowners, for example, were very resistant to selling and far more likely to tap into savings or other assets. In other contexts, however, reverse mortgages and equity release products have been developed to enhance the realisation of housing assets without requiring homeowners to move. In the UK, a leader in financial product development, $20 \%$ of all mortgage lending was made up of equity release leading up to the credit crunch (Quilgars and Jones 2007). Toussaint and Elsinga (2009) distinguish between traditional and new 'housing-asset-based welfare'. In the former, home ownership is perceived as a means to accumulate housing equity that can be tapped into contingently, as a last resort. In the latter, home equity is used as a financial resource and built up or released as needed over the life course via financial products. The problem for governments is that with 'traditional' housing-asset-based welfare there is considerable resistance to the use of homes as welfare resources. Meanwhile, 'new' systems have over-stimulated consumption, with equity turned into lifestyle consumption, leaving little of the housing asset left when it is needed in later life. 
A fourth issue concerns the housing market itself. Housing-asset-based welfare is founded on the assumption that house prices increase faster than inflation, and in perpetuity. Although housing markets in many countries have demonstrated increases in the long term, markets are evidently volatile. Consequently many are respectively advantaged or disadvantaged by their timing of entry and exit in the market. Whatever the consequences of this for the individual, it also provides challenges for governments. For the Singapore government, for example (with a heavily embedded asset-based welfare system), while enjoying considerable political support for their mass home ownership programme (with public schemes accounting for more than $80 \%$ of the housing stock and a total owneroccupancy rate of $92 \%$ ), policy objectives have become subordinate to the maintenance of house price values. So much individual wealth is held in housing assets that housing market crashes threaten not only the aggregate asset value of the nation but also the viability of the welfare and pension system (Chua 2003).

Finally, the volatility of housing markets exposed in recent years has also revealed some inherent unsustainability in property-based welfare systems. Such a system can only be expected to survive if continual access to home ownership assets is guaranteed from one generation to the next. However, it recently became evident in most active housing markets that distinct classes of 'market included' and 'market excluded' were beginning to form as a result of house price inflation. This constituted a division in interests between two parts of the population, with one that had secured access to asset-based welfare via the housing market on one side, and one seeking access on the other (Watson 2009; Ronald 2008). While the former have an interest in the continued increase in house prices and government persistence with asset-based welfare strategies, the latter have pressured governments to improve access and the affordability of home purchase. Watson argues that under current economic conditions, governments face a dilemma between the short- and long-term needs of developing asset-based welfare. While they cannot afford to let property values fail, they also recognise that the next generation of aspiring asset holders will be excluded from accumulation dynamics on the housing market unless affordable housing becomes more widely available.

\section{An international perspective}

So, what insights and understandings of these issues related to asset-based welfare founded on home ownership does the collection of papers in this themed edition contribute?

Much of the recent literature dealing with the complex relationship between housing and welfare and the challenges facing the implementation and maintenance of asset-based welfare has focused on Anglo-American contexts. This has perpetuated an assumption that asset-based welfare is relatively innovative and an association between its advancement and advanced liberal regimes. However, a more international perspective reveals that aspects of asset-based welfare are evident in a variety of contexts and that home ownership is already well developed in many countries as an explicit means to supplement or substitute public welfare provision (Doling and Ronald 2008). Furthermore, a more comparative appraisal reveals a more nuanced and complex interaction between housing policy, markets and welfare systems that demonstrates significant path dependency and local contingency. The papers presented in this themed issue provide some insight into this diversity and complexity. They illustrate not only the potential and limitations of assetbased welfare systems, but also provide insights into how the challenges we have highlighted so far can be negotiated, resolved or, alternatively, how they can persist. Moreover, 
they illustrate new issues, especially in societies where home ownership has a more mature base in the welfare system and logic of the state.

Yosuke Hirayama's paper on Japan is one of two from the Asia-Pacific region. Among industrialized East Asian nations, housing has received special treatment in policy. Governments have been strongly interventionist in the housing sector but have in the long term promoted the consumption of housing as a household investment good (Doling 1999; Groves et al. 2007; Ronald 2007). Home ownership has indeed been central to welfare conditions. The sustained house price increases between the 1960s and 1990s improved family economic capacity, supporting state underdevelopment of public welfare in favour of a policy regime devoted to economic growth. Japan pioneered an East Asian welfare capitalism model. Post-war housing policies sought to rapidly expand owner-occupancy levels and embed the relationship between family housing wealth and welfare self-provision. Until the 1990s, the government was consistent in stimulating house price inflation, which it considered both central to the transfer of aggregate national wealth increases to the household level and necessary to social security self-reliance.

Hirayama identifies key challenges to this system, including a prolonged era of economic decline in the 1990s and 2000s, on the one hand, and a rapidly ageing population, on the other. Japan can be considered a mature asset-based welfare system that has been almost irrevocably damaged by more than 12 years of asset depreciation. There are now considerable gaps in welfare, especially for the elderly, that the government is attempting to plug. Moreover, traditional mechanisms for maintaining a 'home-owning society' are failing. Home purchase for younger households has been in sharp decline. Meanwhile economic conditions between categories of homeowner and housing property have become noticeably differentiated, aggravating inequalities. Hirayama's focus is the sustainability of a home-ownership-based welfare approach in Japan in terms of emerging inter- and intragenerational inequalities. Japan's extraordinarily large elderly population are disproportionately cash-poor housing-asset-rich, which is reshaping the distribution and function of housing wealth, thereby undermining the asset-based regime.

The second article from this region, by Judy Yates and Bruce Bradbury, treats the case of Australia, where there has been a long-standing reliance on home ownership as an individualistic mechanism for building wealth and enhancing living conditions in retirement in the context of a 'workfare' approach to public provision (see Castles 1998). This paper examines how home ownership can potentially protect households from poverty in retirement. It also addresses likely future trends in asset accumulation, suggesting that, although asset-based welfare potentially eases fiscal constraints upon the state, it may well lead to poorer social insurance outcomes for households with limited saving capacity over their lifetimes.

Unlike many other advanced nations, more than $80 \%$ of retired Australians own their own home and most are outright owners. Thus, while the incomes of older Australians are comparatively low, once housing costs are taken into account, the after-housing poverty rate for older households is not so unusual. However, after-housing-costs poverty rates for non-home-owning older households are notably high. Projections suggest that this group will grow in size in the coming decades, leading to the collapse in approaches to retirement incomes incorporating outright home ownership.

Srna Mandic's paper explores transformations in housing and economic regimes in the transition states of Eastern Europe. Mandic highlights how collectivist forms of welfare and housing provision gave way to more individualised risk coverage and privatised housing consumption during the economic transition of the 1990s and 2000s. Home ownership expanded on a massive scale and the ostensible wealth it generated offset many imbalances 
in emerging welfare regimes. In assessing the future potential of housing assets in Eastern Europe to 'sustain, store and release wealth', she analyses micro data from the European Quality of Life Survey. This reveals a relatively high incidence of unfit housing as well as considerable deprivation among homeowners. The nature of the housing stock and housing system in many East European contexts suggests that owner-occupied housing has a more limited capacity to store and sustain wealth in comparison to Western Europe. Mandic also identifies considerable within-group differences in the region. Among European postsocialist countries she specifically identifies three sub-groups within which there is more or less dependence on home ownership in offsetting welfare or pension income, and more or less potential to develop the housing system to enhance the function of asset-based welfare.

The paper by the editors also addresses contrasts between groups of countries across the European Union, taking the increased 'potential' in asset-based welfare across Europe engendered by overall advances in home ownership rates and property values in the last decade as a point of departure. Based on analyses of aggregate data, the potential for home ownership to supplement pensions is examined in each country. This requires some considerable approximations of types and rates of income homeowners could hypothetically generate from their homes. It also involves consideration of pension systems in each country and how they operate in relation to housing as well as other sources of wealth and income in old age. Central to the measure of asset-based welfare viability is the notion of 'adequacy' by which is meant how potential retirement incomes compare to working incomes in bringing retired households out of poverty. The analysis provides broad comparisons between EU member states with regard to existing housing and pension conditions. It appears that housing income may have least impact in older EU member states in Central and Northern Europe and greatest in Eastern Europe, Mediterranean countries and the 'liberal' nations on the Atlantic rim including Britain and Ireland. Another distinction appears to exist between Eastern transition economies and liberal West and Southern European ones. Even though East European state pension systems make a small contribution to older people's incomes, they are relatively large compared to the incomes of younger people, and the risk of poverty in old age is almost as low as it is in North-Central European countries. In liberal and Mediterranean countries, while state pensions make a significant contribution, the incomes of younger people are notably higher and there is greater risk of poverty in old age. An important conclusion is that greater dependency on home ownership in welfare provision, particularly applied as a substitute for rather than a complement to existing arrangements, may have adverse consequences, especially for the most vulnerable households. Indeed, various studies indicate that home ownership and housing wealth reinforce rather than compensate for existing inequalities.

The final paper looks in greater depth at a North-Western European home ownership orientated society that has been somewhat neglected in international analyses. In comparison to its neighbours, Belgium has much greater dependency on housing self-provision, rooted in the consistent promotion of home ownership since the nineteenth century. Based on both qualitative and quantitative analyses of household perceptions, expectations and conditions, Pascal De Decker and Caroline Dewilde assert that an asset-based approach to welfare has actually long been in place. Older Belgian people tend to be income-poor but housing-asset-rich. Home ownership is not simply a cultural preference, however, but necessary to offset poverty risk in retirement, which is high among elderly renters. Nonetheless, Belgium's asset-based welfare appears to demonstrate features of a more 'traditional' system of housing-asset-based welfare with a strong reliance on reduced housing costs in old age rather than the release of housing equity. Moreover, attitudes towards welfare are relatively conservative and the expectation that the state can and 
should provide unemployment and welfare benefits as well as state pensions to supplement retirement income is strongly rooted. Crucially, housing is considered a private issue and separated from the social security sphere, which has limited and shaped the policy debate in Belgium.

\section{Concluding comments}

Looking across the papers, it is possible to highlight some core issues generated by a comparative appraisal. First is the interaction between housing, pensions, employment and welfare institutions and practices, which manifest and combine distinctively in different contexts. These combinations shape not only the effectiveness of housing-asset-based welfare but also the scale and directions in which the overall system can be developed. Second are the differences in home ownership systems, including housing markets, housing stock, housing finance and equity release, home building and purchase practices. Differences in these dimensions may inhibit or enhance the potential of housing as an asset. A third issue concerns the features of ageing populations and their relative wealth, housing or otherwise, in relation to both other generations and within the cohort. An emergent feature of asset-based welfare systems is the divide between different generations of home buyers whose relative market advantage can disadvantage those who follow. This is evident across societies from the UK to Slovenia and Japan.

These diverse analyses of different approaches to home ownership and asset-based welfare, then, provide new and provocative insights. In recent years, debates on the direction of housing and welfare policy have often been guided by assumptions derived from a preponderance of Anglo-American cases and perspectives. In the wake of the current credit crisis and emergent features of a new socioeconomic era, there is even greater urgency in regard to the re-assessment of welfare inequalities and reorientation of social security policies. The examples, analyses and arguments contained in this themed edition can hopefully inform policy debates and provide lessons for the restructuring of housing and social security systems. At the very least, each of these articles informs an understanding of the potential and limitations of asset-based systems of welfare provision while highlighting future issues and concerns regarding this approach to social risk and poverty reduction.

Open Access This article is distributed under the terms of the Creative Commons Attribution Noncommercial License which permits any noncommercial use, distribution, and reproduction in any medium, provided the original author(s) and source are credited.

\section{References}

Allen, J., Barlow, J., Leal, J., Maloutas, T., \& Padovani, L. (2004). Housing and welfare in Southern Europe. Oxford: Blackwell.

Castles, F. (1998). The really big trade-off: Home ownership and the welfare state in the new world and the old. Acta Politica, 33(1), 5-19.

Castles, F. G., \& Ferrera, M. (1996). Home ownership and welfare: Is southern europe different? South European Society and Politics, 1(2), 163-185.

Chua, B.-H. (2003). Maintaining housing values under the condition of universal homeownership. Housing Studies, 18(3), 765-780.

Conley, D., \& Gifford, B. (2003). Home ownership, social security and the welfare state. New York University. http://www.nyu.edu. 
Dewilde, C., \& Raeymaeckers, P. (2008). The trade off between home ownership and pensions: the individual and institutional determinant of old-age poverty. Ageing and Society, 28, 805-830.

Doling, J. (1999). Housing policies and the little tigers: how do they compare with the other industrialized countries. Housing Studies, 14(2), 229-250.

Doling, J., \& Ford, J. (2007). A union of home owners, editorial. European Journal of Housing and Planning, 7(2), 113-127.

Doling, J., \& Ronald, R. (2008). Housing as a pension, Report to the European Commission, DEMHOW Working Paper.

Fahey, T., Nolan, B., \& Maitre, B. (2004). Housing expenditures and income poverty in EU countries. Journal of International Social Policy, 33(3), 437-454.

Groves, R., Murie, A., \& Watson, C. (2007). Housing and the new welfare state: Examples from East Asia and Europe. Aldershot: Ashgate.

Haffner, M. (2008). Savings for old age? Housing wealth of the Dutch elderly. Housing Theory and Society, 25(2), 110-131.

Kemeny, J. (1981). The myth of home ownership: Public versus private choices in housing tenure. London: Routledge.

Langley, P. (2008). The everyday life of global finance: Saving and borrowing in Anglo-America. Oxford: Oxford University Press.

Malpass, P. (2008). Housing and the new welfare state: Wobbly pillar or cornerstone? Housing Studies, 23(1), 1-19.

McKay, S. (2002). The saving gateway: 'asset-based welfare' in action? Benefits, 10(2), 141-145.

Quilgars, D., \& Jones, A. (2007). United Kingdom: As safe as houses? In M. Elsinga, P. De Decker, N. Teller, \& J. Toussaint (Eds.), Beyond asset and insecurity: On (In)security of home ownership in Europe. Amsterdam: IOS Press.

Regan, S., \& Paxton, W. (2001). Asset-based welfare: International experiences. London: IPPR.

RICS. (2007). Housing accessibility and affordability update for Great Britain. London: Royal Institute of Chartered Surveyors.

Ritakallio, V. M. (2003). The importance of housing costs in cross national comparisons of welfare (state) outcomes. International Social Security Review, 56(2), 81-101.

Ronald, R. (2007). Comparing homeowner societies: Can we construct an east-west model? Housing Studies, 22(4), 473-493.

Ronald, R. (2008). The ideology of home ownership: Homeowner societies and the role of housing. Basingstoke: Palgrave.

Rowlingson, K. (2002). Private pension planning: the rhetoric of responsibility, the reality of insecurity. Journal of Social Policy, 13(4), 623-642.

Sherraden, M. (2003). Assets and the social investment state. In W. Paxton (Ed.), Equal shares: Building a progressive and coherent asset based welfare policy (pp. 28-41). London: IPPR.

Torgersen, U. (1987). Housing: The wobbly pillar under the welfare state. Scandinavian Journal of Housing and Planning Research Supplement, 4(1), 116-127.

Toussaint, J., \& Elsinga, M. (2009). Exploring 'housing and asset-based welfare' can the UK be held up as an example for Europe? Housing Studies, 24(5), 669-692.

Watson, M. (2009). Planning for the future of asset-based welfare? New Labour, Financialized economic agency and the housing market. Planning, Practice and Research, 24(1), 41-56. 